\title{
Leptin and leptin receptor polymorphisms are associated with poor outcome (death) in patients with non-appendicular secondary peritonitis
}

\author{
Rodolfo L Bracho-Riquelme ${ }^{1,2^{*}}$, Verónica Loera-Castañeda ${ }^{3}$, Alejandro Torres-Valenzuela ${ }^{4}$, \\ Guadalupe A Loera-Castañeda ${ }^{3}$ and J Pablo Sánchez-Ramírez ${ }^{2,4}$
}

\begin{abstract}
Introduction: Leptin (LEP) and its receptor (LEPR) participate in the immunological response during infection. LEP serum levels rise during sepsis. In patients with peritonitis, an insufficient elevation in serum LEP is associated with an increased risk of death. As gene variants of LEP and LEPR have been associated with diverse pathologic conditions, we explored the association of genetic polymorphisms of LEP or LEPR with death in patients with secondary peritonitis.
\end{abstract}

Methods: A case control study was undertaken. LEP Gene -2548G > A and the LEPR Gene 223A > G polymorphism were determined in 74 patients. The odds ratio of genotype and allele distribution in survival (control) versus death (case) among patients was calculated. Serum LEP, interleukin (IL)-6, tumour necrosis factor alpha, C-reactive protein (C-RP), IL-10 and IL-13 levels were analyzed in 34 patients.

Results: There were significant differences in genotype and allele distribution between survivors and non-survivors for $-2548 \mathrm{G}>\mathrm{A}$ and $223 \mathrm{~A}>\mathrm{G}$ polymorphisms. The presence of the mutant allele $\mathrm{A}$, in -2548, had an odds ratio of $4.64(95 \% \mathrm{Cl} 1.22,17.67)$ with significance $(P=0.017)$ in the risk of death. The presence of mutant allele $\mathrm{G}$, in 223 , had an odds ratio of $3.57(95 \% \mathrm{Cl} 1.06,12.01)$ with significance in the risk of death $(P=0.033)$. The presence of allele $\mathrm{A}$ in the -2548 polymorphism was associated with differences in serum LEP $(P=0.013)$, and IL-10 ( $P=$ 0.0001). The presence of allele $G$ in 223 polymorphism was likewise correlated with differences in serum LEP $(P<$ 0001), C-RP $(P=0.033)$, and IL-10 $(P=0.043)$.

Conclusions: The polymorphisms studied are associated with death in patients with peritonitis of nonappendicular origin. This association is stronger than many known risk-factors related to peritonitis severity, and is independent of body mass. The physiopathologic mechanism is possibly related to an insufficient increase in the elevation of serum LEP levels, and is unrelated to body mass.

\section{Introduction}

Leptin (LEP) is a cytokine-like hormone that is primarily synthesized and secreted by white adipose tissue. As a hormone it has important functions in the regulation of body weight, reproduction, immune functions, bone formation and growth [1]. The biological activities of LEP on target tissues are carried out through selective binding to a specific receptor. Leptin receptors (LEPR) form

\footnotetext{
* Correspondence: rudybracho@yahoo.com.mx

'Instituto de Investigación Científica, Universidad Juárez del Estado de Durango, Calle Constitución 404 sur, Durango, Dgo. C.P. 34, 000, México Full list of author information is available at the end of the article
}

homodimers that, in general, act by signaling via the Janus kinases to regulate multiple events in target tissues [2].

LEP and LEPR participate in the immunological response during infection. LEP displays both pro- and anti-inflammatory properties. It appears necessary for the induction of interleukin (IL)-6 and tumour necrosis factor alpha (TNF- $\alpha$ ) after a lipopolysaccharide (LPS) challenge, while at the same time it provides protection against LPS- or TNF $\alpha$-induced lethality $[3,4]$. In humans, LEP levels are higher during sepsis [5-7]. In surgically treated patients with peritonitis, an insufficient

\section{Biomed Central}


rise in serum LEP ( $<10 \mathrm{ng} / \mathrm{mL}$ ) is associated with a threefold-increase in the risk of death (sensitivity 94.4, specificity 50\%) [8].

Gene variants of $L E P$ and $L E P R$ have been associated with obesity, non-Hodgkin's lymphoma, non-insulindependent diabetes mellitus, and essential hypertension [1,9-12]. The purpose of this study was to explore the association of genetic polymorphisms of LEP or LEPR with an unfavourable outcome (death) in patients with non-appendicular secondary peritonitis.

In an attempt to explain the low specificity of the above mentioned LEP threshold, we hypothesized that $L E P$ and $L E P R$ polymorphisms cause problems with ligand-receptor binding, contributing to an unfavourable outcome.

A positive association between $L E P$ or $L E P R$ polymorphisms and outcome; serum TNF- $\alpha$, IL-6 (proinflammatory cytokines), IL-10 and IL-13 (anti-inflammatory cytokines), C-RP (acute phase protein), and LEP, illustrating the overall acute phase response, would give us an insight into the causes of the unfavourable outcome.

\section{Materials and methods Patients}

Eligible patients were $\geq 18$ years old, with surgically confirmed secondary peritonitis, defined as a polymicrobial infection of the peritoneum occurring as a consequence of traumatic, infectious, ulcerative, obstructive or neoplastic pathology [13]. All were admitted to the Department of General Surgery of the Hospital General de Durango (Mexico). Excluded were patients with any condition causing immune-depression, current treatment with an immune-suppressive drug, and peritonitis of appendicular origin. Appendicular peritonitis was excluded because it generally has a favourable outcome $[14,15]$. The case-group (non-survivors) included patients that died after $24 \mathrm{~h}$ and within the 30-day postoperative period. The control-group (survivors) was comprised of those who survived the 30-day follow-up. The Ethics Committee at the Hospital General de Durango (SSD) approved the study. Signed informed consent was obtained from each patient.

The 74 patients recruited consisted of all consecutively eligible patients. The sample was prospective. The first of the patients also participated in a published study, and the last 40 participated exclusively in this protocol [8].

The severity of peritonitis was determined using the Mannheim Peritonitis Index (MPI). The score takes in to account eight adverse factors: age $>50$ years ( 5 points), female gender ( 5 points), multiple organ failure (MOF) (7 points), neoplasia ( 4 points), $>24$ h of evolution (4 points), non-colonic origin (4 points), generalized peritonitis (6 points), with purulent (6 points) or fecaloid (12 points) character. The MPI classifies severity in intervals: grade I ( $<21$ points), grade II (21 to 29 points), and grade III ( $>29$ points). It is a simple scoring system, widely used, and is specific to peritonitis. With this index, the grade-response relation between severity of peritonitis and the concentration of key regulatory serum cytokines has been demonstrated [16].

To assess the patients' nutritional status, the Body Mass Index (BMI) was used. Each individual was classified as follows: underweight $\left(<18.5 \mathrm{~kg} / \mathrm{m}^{2}\right)$, normal (18.5 to $24.9 \mathrm{~kg} / \mathrm{m}^{2}$ ), grade I overweight ( 25.0 to 29.9 $\mathrm{kg} / \mathrm{m}^{2}$ ), obese or grade 2 overweight $(30.0$ to $39.9 \mathrm{~kg} /$ $\left.\mathrm{m}^{2}\right)$, grade 3 overweight or morbid obese $\left(>40 \mathrm{~kg} / \mathrm{m}^{2}\right)$ [17].

In accordance with accepted practice principals, the attending physician determined the treatment in each case: correcting fluid and electrolyte deficiencies with parenteral fluids; physiologic organ system support; surgical treatment (source control, peritoneal lavage and drainage) during open exploratory laparotomy along with broad-spectrum antibiotic therapy $[18,19]$.

\section{Procedures}

\section{DNA extraction and LEP, LEPR genotyping}

DNA was extracted from leukocytes using the DTAB/ CTAB method previously described [20]. Gene amplification was performed by the conventional polymorphism chain reaction (PCR) using the following primers: for the LEP gene: forward 5'TTTCCTGTAATTT TCCCGTGAG-3' and reverse 5'AAAGCAAAGACAGGCATAAAAA-3'. Amplification of a 242 bp fragment ensued under the following reaction conditions: initial denaturing at $95^{\circ} \mathrm{C}$ for five minutes and 30 amplification cycles of $94^{\circ} \mathrm{C}, 58.5^{\circ} \mathrm{C}$ and $72^{\circ} \mathrm{C}$ for one minute and a final extension at $72^{\circ} \mathrm{C}$ for five minutes. For the $L E P R$ gene, we used the following primers: forward 5'AAACTCAACGACACTCTCCT-3' and reverse 5'TGAACTGACATTAGAGGTGAC-3'. This gave rise to a product of 80 bp using the following amplification conditions: $94^{\circ} \mathrm{C}$ $\times 2$ minutes of initial denaturing, followed by 32 cycles of $94^{\circ} \mathrm{C}$ for 1 minute, $50^{\circ} \mathrm{C}$ for $45 \mathrm{sec}$ and $72^{\circ} \mathrm{C}$ for 30 sec, with a final extension of 7 minutes. After PCR all products were stored at $4^{\circ} \mathrm{C}$.

For the restriction fragment length polymorphism (RFLPs), these PCR products were digested with restriction enzymes, using Cofl Promega ${ }^{\circledR}$ (Madison, WI. USA) $1.0 \mathrm{U}$ per $15 \mu \mathrm{L}$ of the product of PCR was incubated at $37^{\circ} \mathrm{C}$ for 60 minutes for the $-2548 \mathrm{G}>\mathrm{A}$ polymorphism in the $L E P$ gene, generating a restriction pattern of 61 bp and $181 \mathrm{bp}$ when the cleavage site is present. On the other hand the enzyme MspI Sigma ${ }^{\circledR}$ (Saint Louis, MO. USA) $1.5 \mathrm{U}$ per $15 \mu \mathrm{L}$ of the product of PCR was incubated at $37^{\circ} \mathrm{C}$ for 60 minutes was used for polymorphism $223 \mathrm{~A}>\mathrm{G}$ of the $L E P R$ gene, which generates a 
cleavage site that produces $22 \mathrm{bp}$ and $58 \mathrm{bp}$ fragments. RFLPs were visualized by means of $2 \%$ agarose gel electrophoresis stained with ethidium bromide [20].

A total of S $1.5 \mathrm{U}$ per $15 \mu \mathrm{L}$ of the product of PCR, incubated at $37^{\circ} \mathrm{C}$ for 60 minutes, was used for polymorphism 223A > G of the LEPR gene, which generates a cleavage site that produces $22 \mathrm{bp}$ and $58 \mathrm{bp}$ fragments. RFLPs were visualized by means of $2 \%$ agarose gel electrophoresis stained with ethidium bromide [20].

\section{Cytokine and C-Reactive protein analysis}

Serum LEP, IL-6, TNF- $\alpha$, C-RP, IL-10 and IL-13 levels were available for the first 34 patients. The blood samples were taken 18 to $24 \mathrm{~h}$ into the postoperative period, irrespective of the time of day. It is during this interval that LEP increases to its maximum postoperative value [21-23].

The samples were allowed to clot, and serum was separated by centrifugation and cryopreserved at $-40^{\circ} \mathrm{C}$, until the time of cytokine and C-RP determination. Thirty-four samples were processed to determine: LEP (ng/ml), TNF- $\alpha(\mathrm{pg} / \mathrm{ml})$, interleukins 6, 10 and 13 (pg/ $\mathrm{ml})$, and C-RP $(\mu \mathrm{g} / 100 \mathrm{ml})$. Each analyte was evaluated separately using standard ELISA methods: IL-6 and IL10 were determined with Quantikine ${ }^{\circledR}$ HS (R\&D Systems, Minneapolis, MN, USA), LEP, IL-13, and TNF- $\alpha$ with Quantikine ${ }^{\circledR}$ kits (R\&D Systems). C-RP was determined with the AlerChek kit for C-RP (AlerCHEKTM, Portland, ME, USA).

\section{Statistical analysis}

For the sample size calculation we took into consideration frequencies of $77.4 \%$ and $70.14 \%$ for polymorphisms $-2548 \mathrm{G}>\mathrm{A}$, and 223A > G respectively, in accordance with Wang et al. in patients with morbid obesity and resistance to insulin [24]. Therefore, an average prevalence of $75 \%$ was considered adequate to calculate our sample size, with a variation up to a $10 \%$. Using program EPIDAT (formula $n=\mathrm{Z}^{2} \mathrm{pq} / \mathrm{d}^{2}$ ) we calculated a sample $n=73$.

Categorical variables were reported as counts, percentages and $95 \% \mathrm{CI}$, and continuous variables as means \pm $\mathrm{SD}$, median and percentiles. For categorical variables, the chi-square test was used to assess differences. For continuous variables, a t-test and ANOVA were employed. Odds ratios (OR) and confidence intervals were calculated. $P$-values less than 0.05 indicated statistical significance. Data were collected and analyzed using the SPSS V. 15.0.1 (SPSS Inc. Chicago, IL, USA, 2006) and Epidat 3.1 (Xunta de Galicia/PHO, A Coruña, Galicia, España, 2006) software.

\section{Results}

\section{Study population}

The case-control population comprised 74 adults (41 males and 33 females, mean age: $54.7 \pm 21.1$ years). The non-survivors were 22 patients (10 males and 12 females, mean age: $68.5 \pm 14.6$ years). The survivors were 52 patients ( 31 males and 21 females, mean age: $48.8 \pm 20.8$ years). The mean hospital stay for all patients was $7.15 \pm 5.73$ days. A mean BMI of $24.75 \pm$ 3.82 , along with the low total proteins, albumin, and A/ $\mathrm{G}$ ratio (Table 1), suggest malnutrition. A low mean erythrocyte count, haemoglobin, and hematocrit coincide with this appraisal. The mean MPI of the case-control population was $23.12 \pm 9.10$ points. A high white blood cell count, with bandemia, along with high total bilirubin and direct bilirubin (Table 1), reflect the severity of the sepsis among the study subjects.

The sources of secondary peritonitis were the small intestine $24.32 \%(n=18)$, gallbladder and biliary tree $17.56 \%(n=13)$, colon $16.21 \%(n=12)$, stomach $16.21 \%$ $(n=12)$, liver $13.51 \%(n=10)$, uterus and fallopian tubes $4.05 \%(n=3)$, duodenum $4.05 \%(n=3)$, pancreas $1.35 \%(n=1)$, spleen $1.35 \%(n=1)$, and retroperitoneum $1.35 \%(n=1)$.

\section{Clinical characteristics}

Comparing survivors and non-survivors, there was a difference in age $(P=0.0001)$, but there was neither a difference in sex-ratio $(P=0.3874)$, nor in hospital stay in days $(P=0.828)$. With respect to BMI categories of underweight ( $n=0$ vs. 3), normal (26 vs. 11), grade I overweight (20vs. 6), and obese (6vs. 2), there was no difference $(P=0.052)$ between controls and cases. There were differences in total proteins $(P=0.006)$, albumin $(P=0.0001)$, and in the $\mathrm{A} / \mathrm{G}$ ratio $(P=0.0001)$, between survivors and non-survivors, and in MPI scores $(P<$ 0.0001).

Comparing the MPI adverse factors between each group (Table 2), a difference was found for age $>50$ years $(P=0.0076)$, generalized peritonitis $(P=0.0483)$, the presence of MOF $(P<0001)$, and coexisting neoplasia $(P=0.0007)$.

\section{Comparison of genetic characteristics}

The genotypic distribution of the alleles represented by the polymorphism of the leptin gene at -2548 was in Hardy-Weinberg equilibrium ( $P$-value of two-tailed chisquare 0.113807 ), while the genotype distribution of polymorphism 223 was in disequilibrium ( $P$-value of two tailed chi-square 0.023312).

\section{-2548 polymorphism}

Analysis of the allele distribution in survival versus death among patients with non-appendicular secondary peritonitis (Table 3) showed a higher frequency of the A allele among those with an unfavourable outcome $(P=$ 0.002). Considering a dominant model, an odds ratio of 4.64 (95\% CI 1.22, 17.67) with statistical significance $(P$ $=0.017)$ was found using contingency tables with $\mathrm{A} / \mathrm{A}+$ 
Table 1 Mean laboratory findings in $\mathbf{7 4}$ patients with non appendicular secondary peritonitis

\begin{tabular}{|c|c|c|c|}
\hline Study & Mean & Reference value & 95\% confidence interval \\
\hline Erythrocytes & $4.22 \pm 1.11 \times 10^{6}$ & 4.5 to 6.0 male, 4.2 to $5.4 \times 10^{6}$ female & $(3.76,4.68)$ \\
\hline Hemoglobin & $12.79 \pm 3.47 \mathrm{~g} / \mathrm{dL}$ & 12 to 17 male, 11 to $15 \mathrm{~g} / \mathrm{dL}$ female & $(11.36,14.22)$ \\
\hline Hematocrit & $38.55 \pm 10.31 \%$ & 41 to 52 male, 38 to $46 \%$ female & $(34.29,42,81)$ \\
\hline Neutrophils & $61.76 \pm 27.27 \%$ & 50 to $70 \%$ & $(50.50,73.02)$ \\
\hline Bands & $15.92 \pm 15.94 \%$ & 0 to $3 \%$ & $(9.34,22.50)$ \\
\hline Platelets & $288,543 \pm 160,829$ plts. & 150 to $350 \times 10^{3}$ & $(222,156.05,354,929.95)$ \\
\hline Total proteins & $5.49 \pm 1.11 \mathrm{~g} / \mathrm{dL}$ & 6.5 to $8.0 \mathrm{~g} / \mathrm{dL}$ & $(5.23,5.76)$ \\
\hline Albumin & $2.46 \pm 0.77 \mathrm{~g} / \mathrm{dL}$ & 3.5 to $5.0 \mathrm{~g} / \mathrm{dL}$ & $(2.28,2.65)$ \\
\hline Globulins & $3.03 \pm 0.63 \mathrm{~g} / \mathrm{dL}$ & 2.5 to $3.5 \mathrm{~g} / \mathrm{dL}$ & $(2.88,3.18)$ \\
\hline $\mathrm{A} / \mathrm{G}$ ratio & $0.82 \pm 0.27$ & 1.3 to 2.5 & $(0.76,0.89)$ \\
\hline Total bilirubin & $1.42 \pm 1.8 \mathrm{~g} / \mathrm{dL}$ & up to $1.1 \mathrm{~g} / \mathrm{dL}$ & $(1.00,1.84)$ \\
\hline Direct bilirubin & $0.788 \pm 1.66 \mathrm{~g} / \mathrm{dL}$ & up to $0.25 \mathrm{~g} / \mathrm{dL}$ & $(0.40,1.18)$ \\
\hline Indirect bilirubin & $0.645 \pm 0.49 \mathrm{~g} / \mathrm{dL}$ & 0.1 to $0.5 \mathrm{~g} / \mathrm{dL}$ & $(0.53,0.76)$ \\
\hline
\end{tabular}

G/A in the rows as the presence of an adverse factor versus $\mathrm{G} / \mathrm{G}$, and in the columns, survival versus death.

\section{3 polymorphism}

Analysis of the allele distribution (Table 3) in the controls versus cases showed a non-significant trend toward higher frequency of the $\mathrm{G}$ allele among non-survivors $(P$ $=0.011)$. Analyzing $\mathrm{G} / \mathrm{G}+\mathrm{G} / \mathrm{A}$, as an adverse factor versus $\mathrm{A} / \mathrm{A}$, while comparing the outcome, survival versus death, showed a difference, $(P=0.033)$ with an odds-ratio of 3.57 (95\% CI 1.06, 12.01).

\section{Association of genetic polymorphisms with clinical characteristics}

Other than death, with an odds-ratio of $4.6(P=0.017)$ for -2548 polymorphism, and with an odds-ratio of $3.6(P=$ 0.0334 ) for 223 polymorphism, no other clinical variable was found associated with either genetic polymorphism (Table 4).

\section{Cytokines}

The presence of mutant allele A (21/34) with respect to -2548 polymorphism was associated with differences in serum $\operatorname{LEP}(P=0.013)$, and IL-10 $(P=0.0001)$, compared to the wild type allele $G$. The presence of mutant allele $\mathrm{G}(22 / 34)$ with respect to 223 polymorphism showed a difference in serum $L E P(P<0001)$, C-RP $(P$ $=0.033)$, and IL-10 $(P=0.043)$, compared to the wild type allele A. But, of the aforementioned $P$-values, only serum $L E P$ in the presence of the 223 polymorphism fell in the $95 \%$ CI (Table 5).

If we compare the means of the study subjects with cytokine levels $(n=34)$ with those without these measurements $(n=40)$ there are no statistically significant differences in age $(P=0.197)$, sex $(0.483)$, BMI classification $(P=0.607)$, the presence of -2548 polymorphism $(P=0.472)$ or 223 polymorphism $(P=1.000)$. These subsamples are equivalent, because all enrolled into the study in the manner stated in the Methods section.

\section{Discussion}

The population base of the Hospital General de Durango, SSD is comprised mainly of underprivileged patients that lack access to social security medical

Table 2 Mannheim Peritonitis Index adverse factors present in the $\mathbf{7 4}$ patients with non-appendicular secondary peritonitis

\begin{tabular}{|c|c|c|c|c|}
\hline Characteristic & Survivors (n (\%)) & Non-survivors (n (\%)) & Total (n (\%)) & $P$ \\
\hline Age $>50$ years & $26(50)$ & 19 (86.4) & $45(60.8)$ & 0.0076 \\
\hline Female gender & $21(40.4)$ & $12(54.5)$ & $33(44.6)$ & 0.3874 \\
\hline Generalized peritonitis & $31(60)$ & $19(86.4)$ & $50(67.6)$ & 0.0483 \\
\hline Duration $>24 \mathrm{~h}$ & $44(85)$ & $21(95.5)$ & $65(87.8)$ & 0.3603 \\
\hline Purulent/fecal character & $26(50)$ & $17(77.3)$ & $43(58,1)$ & 0.0554 \\
\hline Non-colonic origin & $44(85)$ & $15(68.2)$ & $59(79.7)$ & 0.1967 \\
\hline Presence of organ failure & $4(7.7)$ & $14(63.6)$ & $18(24.3)$ & $<0.0001$ \\
\hline Malignant disease & $1(1.9)$ & $7(31.2)$ & $8(10.8)$ & 0.0007 \\
\hline MPI I & $2(9.1)$ & $38(73.1)$ & $40(54.1)$ & 0.0000 \\
\hline MPI ॥ & $8(36.4)$ & $8(15.4)$ & $16(21.6)$ & 0.0901 \\
\hline MPI III & $12(54.5)$ & $6(11.5)$ & $18(24.3)$ & 0.0003 \\
\hline
\end{tabular}


Table 3 The genotype and allele distribution among patients with non appendicular secondary peritonitis

\begin{tabular}{cccc}
\hline $\mathbf{- 2 5 4 8}$ polymorphism & $\begin{array}{c}\text { Survivors } \\
\text { (n (\%)) }\end{array}$ & $\begin{array}{c}\text { Non-survivors } \\
\text { (n (\%)) }\end{array}$ & $\boldsymbol{P}$ \\
\hline Genotypes & & & $\mathbf{0 . 0 1 4}$ \\
GG & $22(42.3)$ & $3(13.6)$ & \\
GA & $21(40.4)$ & $9(40.9)$ & \\
AA & $9(17.3)$ & $10(45.5)$ & \\
Alleles & & & $\mathbf{0 . 0 0 2}$ \\
G & $65(62.5)$ & $15(34.1)$ & \\
A & $39(37.5)$ & $29(65.9)$ & \\
& & & \\
223 polymorphism & & & \\
Genotypes & & 9.072 \\
GG & $11(21.15)$ & $9(40.9)$ & \\
GA & $18(34,62)$ & $9(40.9)$ & \\
AA & $23(44.23)$ & $4(18.2)$ & \\
Alleles & & & $\mathbf{0 . 0 1 1}$ \\
G & $40(38.5)$ & $27(61.4)$ & \\
A & $64(61.5)$ & $17(38.6)$ & \\
\hline
\end{tabular}

institutions, which helps to explain the malnutrition observed. In a gross nutritional assessment, we expected no differences between cases and controls. Although there were significant differences between survivors and non-survivors in total proteins, albumin and the A/G ratio, there was no significant difference in BMI, making both groups comparable.

The differences in MPI severity between survivors and non-survivors was expected because the index is prognostic, and as the score increases, so does the probability of a poor outcome.

The lack of Hardy-Weinberg equilibrium in the $L E P R$ 223 polymorphism may be due to a low recombination rate, different to that present in $L E P$ gene polymorphism -2548 , within the promoter region.

Based on previous studies related to $L E P$ and $L E P R$ polymorphisms, differences in LEP levels, and physiological consequences were expected. Due to the fact that LEP gene polymorphism - 2548 is located in the promoter region, it is associated with a low expression of LEP,

Table 4 Relationship between polymorphisms and clinical variables studied in patients with non-appendicular secondary peritonitis.

\begin{tabular}{|c|c|c|c|c|c|c|c|c|c|}
\hline \multirow[b]{2}{*}{ Variable } & \multirow[b]{2}{*}{$\begin{array}{l}\text { Adverse factor/Non- } \\
\text { adverse }\end{array}$} & \multicolumn{4}{|c|}{-2548} & \multicolumn{4}{|c|}{223} \\
\hline & & Carriers & $\begin{array}{l}\text { Non- } \\
\text { carriers }\end{array}$ & $P$ & OR (IC95) & Carriers & $\begin{array}{c}\text { Non- } \\
\text { carriers }\end{array}$ & $P$ & OR (IC95) \\
\hline \multirow[t]{2}{*}{ Age } & $>50$ years & 33 & 12 & 0.1069 & $2.2(0.83,5.99)$ & 32 & 13 & 0.0908 & $2.3(0.87,6.08)$ \\
\hline & $\leq 50$ years & 16 & 13 & & & 15 & 14 & & \\
\hline \multirow[t]{2}{*}{ Sex } & Female & 23 & 10 & 0.5701 & $1.3(0.50,3.53)$ & 20 & 13 & 0.6411 & $0.8(0.31,2.06)$ \\
\hline & Male & 26 & 15 & & & 27 & 14 & & \\
\hline \multirow[t]{2}{*}{ Organ failure } & Present & 16 & 3 & 0.0544 & $3.6(0.93,13.66)$ & 15 & 4 & 0.1050 & $2.7(0.79,9.19)$ \\
\hline & Absent & 33 & 22 & & & 32 & 23 & & \\
\hline \multirow[t]{2}{*}{ Malignancy } & Present & 7 & 1 & 0.1777 & $4.0(0.47,34.49)$ & 7 & 1 & 0.1356 & $4.6(0.53,39.17)$ \\
\hline & Absent & 42 & 24 & & & 40 & 26 & & \\
\hline \multirow{2}{*}{$\begin{array}{l}\text { Time } \\
\text { elapsed }\end{array}$} & $>24 \mathrm{~h}$ & 43 & 22 & 0.9757 & $1.0(0.22,4.29)$ & 43 & 22 & 0.2048 & $2.4(0.60,10.02)$ \\
\hline & $\leq 24 \mathrm{~h}$ & 6 & 3 & & & 4 & 5 & & \\
\hline \multirow[t]{2}{*}{ Origin } & Non colonic & 37 & 22 & 0.2062 & $0.4(0.11,1.66)$ & 35 & 24 & 0.1374 & $0.4(0.09,1.43)$ \\
\hline & Colonic & 12 & 3 & & & 12 & 3 & & \\
\hline \multirow[t]{2}{*}{ Extension } & Generalized & 33 & 17 & 0.9547 & $1.0(0.35,2.72)$ & 34 & 16 & 0.2472 & $1.8(0.66,4.88)$ \\
\hline & Localized & 16 & 8 & & & 13 & 11 & & \\
\hline \multirow[t]{3}{*}{ Exudates } & Fecal & 6 & 0 & 0.1004 & $1.9(0.70,4.95)$ & 5 & 1 & 0.0710 & $2.4(0.92,6.39)$ \\
\hline & Purulent & 25 & 12 & & & 26 & 11 & & \\
\hline & Clear & 18 & 13 & & & 16 & 15 & & \\
\hline \multirow[t]{2}{*}{ Survival } & Survivor & 19 & 3 & 0.017 & $\begin{array}{c}4.6(1.22, \\
17.67)\end{array}$ & 18 & 4 & 0.0334 & $\begin{array}{c}3.6(1.06, \\
12.01)\end{array}$ \\
\hline & Non-survivor & 30 & 22 & & & 29 & 23 & & \\
\hline \multirow[t]{2}{*}{ BMI } & $\begin{array}{l}\text { Overweight/ } \\
\text { obese }\end{array}$ & 22 & 12 & 0.8001 & $0.9(0.34,2.32)$ & 22 & 12 & 0.8443 & $1.1(0.42,2.85)$ \\
\hline & $\begin{array}{l}\text { Normal/ } \\
\text { underweight }\end{array}$ & 27 & 13 & & & 25 & 15 & & \\
\hline
\end{tabular}


Table 5 Relationship between polymorphisms and cytokine/acute phase reactant studied in patients with nonappendicular secondary peritonitis.

\begin{tabular}{|c|c|c|c|c|c|c|c|c|}
\hline \multirow[b]{2}{*}{$\begin{array}{l}\text { Cytokine/Acute phase } \\
\text { reactant }\end{array}$} & \multicolumn{4}{|c|}{-2548} & \multicolumn{4}{|c|}{223} \\
\hline & $\begin{array}{l}\text { Carriers } \\
n=21\end{array}$ & $\begin{array}{c}\text { Non-carriers } \\
n=13\end{array}$ & $P$ & (IC95) & $\begin{array}{c}\text { Carriers } \\
n=22\end{array}$ & $\begin{array}{c}\text { Non-carriers } \\
n=12\end{array}$ & $P$ & (IC95) \\
\hline Leptin & $4.59 \mathrm{ng} / \mathrm{ml}$ & $8.32 \mathrm{ng} / \mathrm{ml}$ & 0.013 & $-3.52,11.04$ & $2.53 \mathrm{ng} / \mathrm{ml}$ & $12.39 \mathrm{ng} / \mathrm{ml}$ & $\begin{array}{c}< \\
0.0001\end{array}$ & $\begin{array}{l}3.176 \\
16.52\end{array}$ \\
\hline IL-6 & $8.35 \mathrm{pg} / \mathrm{ml}$ & $9.10 \mathrm{pg} / \mathrm{ml}$ & 0.684 & $-1.28,2.76$ & $8.82 \mathrm{pg} / \mathrm{ml}$ & $8.27 \mathrm{pg} / \mathrm{ml}$ & 0.130 & $-1.49,2.61$ \\
\hline TNF & $21.80 \mathrm{pg} / \mathrm{ml}$ & $21.75 \mathrm{pg} / \mathrm{ml}$ & 0.483 & $-9.69,9.79$ & $23.06 \mathrm{pg} / \mathrm{ml}$ & $19.43 \mathrm{pg} / \mathrm{ml}$ & 0.598 & $-6.19,13.45$ \\
\hline CRP & $\begin{array}{c}160.39 \mu \mathrm{g} / 100 \\
\mathrm{ml}\end{array}$ & $\begin{array}{l}150.52 \mu \mathrm{g} / 100 \\
\mathrm{ml}\end{array}$ & 0.756 & $\begin{array}{l}-24.47 \\
44.21\end{array}$ & $\begin{array}{l}165.58 \mu \mathrm{g} / 100 \\
\mathrm{ml}\end{array}$ & $\begin{array}{c}140.18 \mu \mathrm{g} / 100 \\
\mathrm{ml}\end{array}$ & 0.033 & $-8.49,59.29$ \\
\hline $\mid \mathrm{L}-10$ & $17.95 \mathrm{pg} / \mathrm{ml}$ & $8.51 \mathrm{pg} / \mathrm{ml}$ & 0.0001 & $-7.95,26.83$ & $13.87 \mathrm{pg} / \mathrm{ml}$ & $15.21 \mathrm{pg} / \mathrm{ml}$ & 0.043 & $\begin{array}{c}-16.66 \\
19.34\end{array}$ \\
\hline IL-13 & $12.71 \mathrm{pg} / \mathrm{ml}$ & $19.60 \mathrm{pg} / \mathrm{ml}$ & 0.910 & $\begin{array}{c}-4,56 \\
18.34\end{array}$ & $17.55 \mathrm{pg} / \mathrm{ml}$ & $11.30 \mathrm{pg} / \mathrm{ml}$ & 0.337 & $-5.45,17.95$ \\
\hline
\end{tabular}

and, consequently, low serum concentrations [9]. LEPR 223 polymorphism, found in the exonic region, causes problems with ligand-receptor binding [12]. Both receptors have been related with obesity, non-Hodgkin's lymphoma, non-insulin-dependent diabetes mellitus, essential hypertension, and resistance to insulin $[10,12]$.

Of the variables studied, the -2548 polymorphism superseded all other variables recognized as adverse factors for an unfavourable outcome. In the case of the 223 polymorphism, only coexistent malignancy surpassed it among the adverse factors studied (Table 4). It stands out that, other than outcome, none of the variables studied was found to be significantly associated to either polymorphism. As far as we know, this is the first report of the association between $L E P$ and $L E P R$ genetic polymorphisms and death, in any form of sepsis.

The LEPR gene 223A > G polymorphism is expected to have an impact on the binding of the hormone to its receptor. A change at the binding site may affect the union between the ligand and its receptor, modifying the intracellular signaling events, thereby influencing the expected physiologic response. The low concentration of LEP and a subsequent loss of its protective effects then has an impact on survival, but the presence of the polymorphism may contribute to this problem, explaining the low specificity of this biomarker, in accordance to a carrier or non-carrier state.

The fact that the poor outcome of patients with -2548 and 223 polymorphisms appears to be due to lower serum levels of LEP coincides with our previous report of a high risk of death in patients with surgically confirmed secondary peritonitis with low serum LEP levels. As suggested by these results, the threshold of $6.6 \mathrm{ng} / \mathrm{ml}$ (confirmed in this sample) should be taken as a predictive marker, as we stated in that publication [8]. LEP increases T-helper cells-1 (Th1) and suppresses Th2 cytokine production, hence its rise in sepsis promotes the host's pro-inflammatory response against its aggressors, and the lack of increase observed favours an antiinflammatory pattern with an unfavourable outcome [25].

Bornstein reported an increase of LEP in sepsis, with lower levels among non-survivors [26,27]. A recent study found that serum LEP is a powerful biomarker that helps to differentiate sepsis from the non-infectious systemic inflammatory response syndrome in critically ill patients [28]. These findings, along with the aforementioned threshold, and our present results, underline the relevance of LEP in sepsis [8].

As to the possible mechanisms by which an insufficient increase in LEP may relate to mortality and systemic inflammation during sepsis, in a murine model, Tschöp et al. suggest that LEP deficiency leads to impaired bacterial clearance at the site of infection, and LEP replacement improves the immune response and reduces organ damage in sepsis. These authors suggest that the protective effect of LEP in sepsis occurs through CNS signalling that coordinates an appropriate immune response [29,30]. Shapiro et al., in mouse endotoxemia and caecal ligation puncture models of sepsis, confirmed a rise in LEP levels in sepsis. Nonetheless, in their studies, exogenously administered LEP increased mortality, resulting in up-regulation of inflammatory mediators during endotoxemia and LEP-mediated endothelial dysfunction [31]. An explanation for these differences may be found in the manner in which each 
author administrated LEP. Tschöp et al. managed LEP replacement with intra-peritoneal injection, intra-cerebro-ventricular or peripheral mini-pumps (subcutaneous), while Shapiro et al. used osmotic pumps implanted into the abdominal cavity, which might not be the best choice if the model of sepsis is peritoneal.

The conflicting literature on LEP and sepsis is related to the type of patient studied, the source of the sepsis, and time of sampling, which is related to the complex dynamics of cytokines [32-34]. These factors must be taken into account so as not to confuse conflicting results with differences in methodology and the design, which is chosen in relation to the purpose of the study. A useful question to ask when reading papers related with research on LEP may be: does this paper study LEP role as a classic hormone in the regulation of body mass or its paper as a cytokine in the systemic inflammatory response?

The sum of these findings underlines the need to further study the role of LEP in sepsis.

Even though the results of the association between outcome and the polymorphism studied are significant, in spite of limitations in size of the sample, further studies with a larger group may show associations with clinical variables, cytokines or acute phase reactants not seen here.

\section{Conclusions}

The $-2548 \mathrm{G}>\mathrm{A} L E P$ gene, and 223A > G LEPR gene polymorphisms are associated with death in patients with surgically confirmed secondary peritonitis of nonappendicular origin. This association is stronger than many known risk-factors related to peritonitis severity, and is independent of BMI. The patho-physiological mechanism is believed to be related to an insufficient increase in the elevation of serum LEP levels during sepsis.

\section{Key messages}

- LEP Gene -2548G > A, and the LEPR Gene 223A > $G$ polymorphisms increase the risk of death in secondary peritonitis with an odds ratio of 4.64 and 3.57 , respectively.

- These polymorphisms are related with an insufficient increase of LEP serum levels in peritonitis.

- The threshold of $6.6 \mathrm{ng} / \mathrm{ml}$ in serum LEP levels is confirmed as an outcome marker.

\section{Abbreviations}

BMI: Body Mass Index; C-RP: C-reactive protein; IL: interleukin; LEP: leptin; LEPR: leptin receptor; LPS: lipopolysaccharide; MOF: multiple organ failure; MPI: Mannheim Peritonitis Index; OR: Odds ratios; PCR: polymorphism chain reaction; RFLPs: restriction fragment length polymorphism; SSD: Secretaría de Salud de Durango; TNF-a: tumour necrosis factor alpha

\section{Acknowledgements}

The study was funded by the Universidad Juárez del Estado de Durango

\section{Author details}

${ }^{1}$ Instituto de Investigación Científica, Universidad Juárez del Estado de Durango, Calle Constitución 404 sur, Durango, Dgo. C.P. 34, 000, México. ${ }^{2}$ Servicio de Cirugía, Hospital General de Durango (SSD), Calle 5 de Febrero esq. con C. Norman Fuentes s/n, Durango, Dgo. C.P. 34, 000, México.

${ }^{3}$ Laboratorio de genómica aplicada, CIIDIR-IPN Unidad Durango, Calle Sigma 119, Durango, Dgo. C.P. 34, 220, México. ${ }^{4}$ Facultad de Medicina y Nutrición, Universidad Juárez del Estado de Durango, Calle Constitución 404 sur, Durango, Dgo. C.P. 34, 000, México.

\section{Authors' contributions}

$\mathrm{RB}$ and JPS conceived and designed the study. JPS and GAL collected the data. VL and GAL carried out the molecular genetic studies and

immunoassays. AT, VL and RB performed the statistical analysis and drafted the manuscript. RB and VL wrote the paper. All authors read and approved the final manuscript

Competing interests

The authors declare that they have no competing interests.

Received: 22 April 2011 Revised: 31 August 2011

Accepted: 23 September 2011 Published: 23 September 2011

\section{References}

1. van der Lende T, Te Pas MF, Veerkamp RF, Liefers SC: Leptin gene polymorphisms and their phenotypic associations. Vitam Horm 2005, 71:373-404.

2. Paracchini $V$, Pedotti P, Taioli E: Genetics of leptin and obesity. Am J Epidemiol 2005, 162:101-114.

3. Halle M, Persson PB: Role of leptin and leptin receptor in inflammation. Am J Physiol Regul Integr Comp Physiol 2003, 284:R760-762.

4. Waelput W, Brouckaert P, Broekaert D, Tavernier J: A role for leptin in the systemic inflammatory response syndrome and in immune response, an update. Curr Med Chem 2006, 13:465-475.

5. Arnalich F, López J, Codoceo R, Jiménez M, Madero R, Montiel C: Relationship of plasma leptin to plasma cytokines and human survival in sepsis and septic shock. J Infect Dis 1999, 180:908-911.

6. Maruna P, Gürlich R, Frasko R, Rosicka M: Ghrelin and leptin elevation in postoperative intra-abdominal sepsis. Eur Surg Res 2005, 37:354-359.

7. Maruna P, Gürlich R, Frasko R, Haluzík M: Serum leptin levels in septic men correlate well with C-reactive protein and TNF-alpha but not with BMI. Physiol Res 2001, 50:589-594.

8. Bracho-Riquelme RL, Reyes-Romero MA, Pescador N, Flores-García Al: A leptin serum concentration less than $10 \mathrm{ng} / \mathrm{ml}$ is a predictive marker of outcome in patients with moderate to severe secondary peritonitis. Eur Surg Res 2008, 41:238-244.

9. Riestra P, Garcia-Anguita A, Viturro E, Schoppen S, de Oya M, Garcés C Influence of the leptin G2548A polymorphism on leptin levels and anthropometric measurements in healthy Spanish adolescents. Ann Hum Genet 2010, 74:335-339.

10. Ben Ali S, Kallel A, Ftouhi B, Sediri Y, Feki M, Slimane H, Jemaa R, Kaabachi N: The -2548G/A LEP polymorphism is associated with blood pressure in Tunisian obese patients. Blood Press 2008, 17:278-283.

11. Willett EV, Skibola CF, Adamson P, Skibola DR, Morgan GJ, Smith MT, Roman E: Non-Hodgkin's lymphoma, obesity and energy homeostasis polymorphisms. Br J Cancer 2005, 93:811-816.

12. Chiu KC, Chu A, Chuang LM, Saad MF: Association of leptin receptor polymorphism with insulin resistance. Eur J Endocrinol 2004, 150:725-729.

13. Suarez ME: Infecciones intraabdominales: Peritonitis y abscesos. Medicrit 2004, 1:146-180.

14. Lansdown MR, Gray AJ, Treasure T, Layer GT: Appendicectomy: who performs it, when and how? Ann R Coll Surg Engl 2006, 88:530-534.

15. Margenthaler JA, Longo WE, Virgo KS, Johnson FE, Oprian CA, Henderson WG, Daley J, Khuri SF: Risk factors for adverse outcomes after the surgical treatment of appendicitis in adults. Ann Surg 2003, 238:59-66.

16. Bracho-Riquelme RL, Reyes-Romero MA, Torres-Valenzuela A, FloresGarcía Al: The grade-response relation between severity of peritonitis 
and serum cytokine concentrations explains Mannheim Peritonitis Index threshold. Surg Infect 2010, 11:379-386.

17. Expert Committee on Physical Status: Physical Status: the Use and Interpretation of Anthropometry: Report of the WHO Expert Committee Geneva: WHO; 1995.

18. Marshall JC, Innes M: Intensive care unit management of intra-abdominal infection. Crit Care Med 2003, 31:2228-2237.

19. Malangoni MA: Contributions to the management of intraabdominal infections. Am J Surg 2005, 190:255-259.

20. Gustincich S, Manfidetti G, Del Sal G, Schneider C, Carninci P: A fast method for high-quality genomic DNA extraction from whole human blood. Biotechniques 1991, 11:298-300, 302.

21. Maruna P, Gürlich R, Frasko R: Dynamics of leptin plasma levels after abdominal surgical procedures. Rozhl Chir 2001, 80:299-303.

22. Maruna P, Gürlich R, Frasko R: Leptin-a new acute phase reactant. Vnitr Lek 2001, 47:478-483.

23. Kaska M, Zivný P: Serum leptin levels in the perioperative period in surgery patients. Rozhl Chir 2002, 81:22-24.

24. Wang TN, Huang MC, Chang WT, Ko AM, Tsai EM, Liu CS, Lee CH, Ko YC: G2548A polymorphism of the leptin gene is correlated with extreme obesity in Taiwanese aborigines. Obesity (Silver Spring) 2006, 14:183-187.

25. Lord GM, Matarese G, Howard JK, Baker RJ, Bloom SR, Lechler RI: Leptin modulates the T-cell immune response and reverses starvation-induced immunosuppression. Nature 1998, 394:897-901.

26. Bornstein SR, Licinio J, Tauchnitz R, Engelmann L, Negrão AB, Gold P, Chrousos GP: Plasma leptin levels are increased in survivors of acute sepsis: associated loss of diurnal rhythm, in cortisol and leptin secretion. J Clin Endocrinol Metab 1998, 83:280-283.

27. Torpy DJ, Bornstein SR, Chrousos GP: Leptin and interleukin-6 in sepsis. Horm Metab Res 1998, 30:726-729.

28. Yousef AA, Amr YM, Suliman GA: The diagnostic value of serum leptin monitoring and its correlation with tumor necrosis factor-alpha in critically ill patients. Crit Care 2010, 14:R33.

29. Tschöp J, Nogueiras R, Haas-Lockie S, Kasten KR, Castañeda TR, Huber N, Guanciale K, Perez-Tilve D, Habegger K, Ottaway N, Woods SC, Oldfield B, Clarke I, Chua S Jr, Faroogi IS, O'Rahilly S, Caldwell CC, Tschöp MH: CNS leptin action modulates immune response and survival in sepsis. J Neurosci 2010, 30:6036-6047.

30. Tschöp J, Dattilo JR, Prakash PS, Kasten KR, Tschöp MH, Caldwell CC: The leptin system: a potential target for sepsis induced immune suppression. Endocr Metab Immune Disord Drug Targets 2010, 10:336-347.

31. Shapiro NI, Khankin EV, Van Meurs M, Shih SC, Lu S, Yano M, Castro PR, Maratos-Flier E, Parikh SM, Karumanchi SA, Yano K: Leptin exacerbates sepsis-mediated morbidity and mortality. J Immunol 2010, 185:517-524.

32. Jeevanandam M, Begay CK, Petersen SR: Plasma leptin levels in trauma patients: effect of adjuvant recombinant human growth hormone in intravenously fed multiple trauma patients. JPEN J Parenter Enteral Nutr 1998, 22:340-346.

33. Quasim T, McMillan DC, Wallace AM, Kinsella J: The relationship between leptin concentrations, the systemic inflammatory response and illness severity in surgical patients admitted to ITU. Clin Nutr 2004, 23:233-238.

34. Langouche L, Vander Perre S, Frystyk J, Flyvbjerg A, Hansen TK, Van den Berghe G: Adiponectin, retinol-binding protein 4, and leptin in protracted critical illness of pulmonary origin. Crit Care 2009, 13:R112.

doi:10.1186/cc10467

Cite this article as: Bracho-Riquelme et al: Leptin and leptin receptor polymorphisms are associated with poor outcome (death) in patients with non-appendicular secondary peritonitis. Critical Care 2011 15:R227

\section{Submit your next manuscript to BioMed Central and take full advantage of:}

- Convenient online submission

- Thorough peer review

- No space constraints or color figure charges

- Immediate publication on acceptance

- Inclusion in PubMed, CAS, Scopus and Google Scholar

- Research which is freely available for redistribution

Submit your manuscript at www.biomedcentral.com/submit
Biomed Central 